\title{
Risk of malnutrition and zinc deficiency in community-living elderly men and women: the Tromsø Study
}

\author{
Jan-Magnus Kvamme ${ }^{1,2, *}$, Ole Grønli ${ }^{3,4}$, Bjarne K Jacobsen $^{5}$ and Jon Florholmen ${ }^{1,2}$ \\ 'Department of Clinical Medicine, Research Group of Gastroenterology and Nutrition, Faculty of Health Sciences, \\ University of Tromsø, N-9037 Tromsø, Norway: ${ }^{2}$ Department of Gastroenterology, University Hospital North \\ Norway, Tromsø, Norway: ${ }^{3}$ Department of Addiction and Specialised Psychiatric Services, University Hospital North \\ Norway, Tromsø, Norway: ${ }^{4}$ Department of Clinical Medicine, Faculty of Health Sciences, University of Tromsø, \\ Tromsø, Norway: ${ }^{5}$ Department of Community Medicine, Faculty of Health Sciences, University of Tromsø, Tromsø, \\ Norway
}

Submitted 31 March 2014: Final revision received 25 September 2014: Accepted 29 September 2014: First published online 6 November 2014

\begin{abstract}
Objective: Elderly people may be at particular risk of $\mathrm{Zn}$ deficiency due to an increased prevalence of malnutrition. The aim of the present study was to evaluate the $\mathrm{Zn}$ status in community-living elderly people at risk of malnutrition.

Design: Cross-sectional population-based survey. Individuals at risk of malnutrition were identified by the Malnutrition Universal Screening Tool. Zn status was assessed by measuring serum Zn. Logistic regression was performed to evaluate the association between the risk of malnutrition and Zn deficiency.

Setting: Municipality of Troms $\varnothing$, Norway.

Subjects: Random sample of 743 men and 778 women aged $65-87$ years.

Results: Zn deficiency was found in $10.1 \%$ of the participants, including $13 \cdot 1 \%$ of the men and $7.3 \%$ of the women. Among the men and women at risk of malnutrition, $31.0 \%$ and $12.7 \%$, respectively, had $\mathrm{Zn}$ deficiency. In a model adjusted for age, gender, serum albumin and smoking status, Zn deficiency was positively associated with the risk of malnutrition $(\mathrm{OR}=2 \cdot 2 ; 95 \%$ CI $1.3,3 \cdot 6)$. Conclusions: Overall, Zn deficiency was found in one out of ten community-living elderly people and was associated with the risk of malnutrition. Our results encourage the assessment of $\mathrm{Zn}$ status in elderly people at risk of malnutrition, with a special emphasis on elderly men.
\end{abstract}

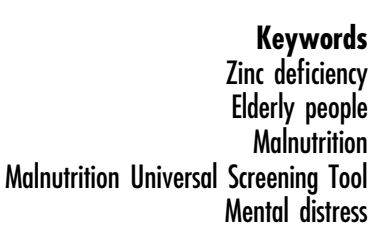

$\mathrm{Zn}$ is an essential micronutrient present in all body tissues and fluids. It is contained in a large number of enzymes. Second only to $\mathrm{Fe}, \mathrm{Zn}$ is the most abundant trace element in $\operatorname{man}^{(1)}$. Mild Zn deficiency may be associated with impaired taste and smell, reduced immunity and increased risk of pneumonia $^{(2,3)}$. In cases of severe $\mathrm{Zn}$ deficiency, skin lesions, anaemia, diarrhoea, anorexia, decreased lymphocyte function, impaired visual function and mental retardation may be observed ${ }^{(4)}$. An increased risk of depression in individuals with $\mathrm{Zn}$ deficiency has been previously reported $^{(5)}$. At present, community-based research on the impact of $\mathrm{Zn}$ deficiency on mental health is scarce.

Important causes of reduced body $\mathrm{Zn}$ include a low intake of $\mathrm{Zn}$-containing foods and a decreased absorption of $\mathrm{Zn}$ due to intestinal malabsorption ${ }^{(2)}$. Meat is a good source of $\mathrm{Zn}$. Additionally, plant-based foods contain $\mathrm{Zn}$. However, phytate in many plants reduces the bioavailability of $\mathrm{Zn}$ from those plants. Worldwide, $\mathrm{Zn}$ deficiency is regarded as a significant contributor to the disease burden, especially among children in developing countries ${ }^{(6)}$. In the developed part of the world, elderly people may be at particular risk for $\mathrm{Zn}$ deficiency due to an increased prevalence of malnutrition ${ }^{(7)}$. However, previous studies from Belgium and the UK exploring the relationship between malnutrition and $\mathrm{Zn}$ deficiency in elderly individuals have yielded conflicting results ${ }^{(8,9)}$.

Moreover, previous studies addressing $\mathrm{Zn}$ status in the general population of elderly men and women have mostly included a limited number of participants; only a few larger population-based studies of $\mathrm{Zn}$ status in elderly people have been conducted. The prevalence of $\mathrm{Zn}$ deficiency has been found to be between 6 and $15 \%{ }^{(10)}$.

Therefore, in the present study, we aimed to evaluate both the $\mathrm{Zn}$ status and the association between $\mathrm{Zn}$ deficiency and risk of malnutrition in a large sample of community-living elderly individuals. 


\section{Methods}

\section{Study population}

The Troms $\varnothing$ Study is a population-based health study of the population of Troms $\varnothing$, a town with 70000 inhabitants in northern Norway ${ }^{(11)}$. The 6th survey of the Troms $\varnothing$ Study was conducted between October 2007 and December $2008^{(12)}$. We restricted our analysis to participants between 65 and 87 years of age, and all inhabitants in this age group ( $n$ 6098) were invited. A total of 4017 men and women participated by going to a study centre for data collection, yielding an overall participation rate of $66 \%$ (4017/6098). Serum from all participating individuals was frozen, and serum $\mathrm{Zn}$ and albumin were later analysed in a random selection of 1765 individuals. The blood collection tubes were free of trace elements and the needles were of standard type. Information on weight loss, height or weight was missing for 200 individuals. Due to laboratory technical problems, forty-four samples were discarded. Consequently, a population of 1521 men and women was included in the present analysis.

\section{Zinc and albumin analysis}

Non-fasting venous blood samples were collected for the measurement of $\mathrm{Zn}$ and albumin using trace-metal-free tubes to avoid contamination. The samples were frozen and stored at $-70^{\circ} \mathrm{C}$, and the serum $\mathrm{Zn}$ was analysed later using flame atomic absorption at a wavelength of 213.9 nm (Perkin Elmer AAnalyst 800 Atomic Absorption Spectrophotometer). Serum Zn concentrations have diurnal variations, with the highest values present in the morning and slightly reduced values present after food intake later in the day ${ }^{(13)}$. The International Zinc Nutrition Consultative Group recommended different serum Zn cutoff values according to gender (men or women), fasting state (non-fasting or fasting) and time of measurement $(\mathrm{AM} \text { or } \mathrm{PM})^{(13)}$. In the present study, the participants visited the research centre between 8 am and 5:30 pm. According to the International Zinc Nutrition Consultative Group guidelines, we applied the non-fasting AM or PM cut-off values for men and women depending on attendance time, i.e. cut-offs of $10 \cdot 7 \mu \mathrm{mol} / \mathrm{l}(\mathrm{AM})$ and $9 \cdot 3 \mu \mathrm{mol} / \mathrm{l}$ (PM) for men and $10.1 \mu \mathrm{mol} / 1$ (AM) and $9.0 \mu \mathrm{mol} / \mathrm{l}(\mathrm{PM})$ for women. Zn deficiency was defined as a serum $\mathrm{Zn}$ level below these cut-off values.

Because a large proportion of $\mathrm{Zn}$ in the serum is bound to albumin $^{(13)}$, an additional assessment of the serum albumin was necessary using the bromocresol green method (Hitachi Modular P, Roche). The lower reference for serum albumin was $34.0 \mathrm{~g} / \mathrm{l}$.

\section{Nutritional assessment}

Height and weight were measured without shoes and in light clothing. BMI was calculated as weight divided by the square of height $\left(\mathrm{kg} / \mathrm{m}^{2}\right)$. The participants were asked if they had involuntarily lost weight during the last 6 months and, if so, how many kilograms they had lost. The weight loss was grouped as below $5 \%$, between $5 \%$ and $10 \%$ or above $10 \%$ of body weight prior to weight loss. Based on both BMI and degree of weight loss, we categorised each individual as being at low, medium or high risk of malnutrition, according to the Malnutrition Universal Screening Tool (MUST; Fig. 1). This tool also has an acute disease component (associated with a lack of nutritional intake for $>5 \mathrm{~d}$ ) that, in our analyses, was set to zero because all of the participants presented at the research centre and were thus regarded as not acutely ill. The weight loss question in the present study was slightly modified to address weight loss over a time span of the 'last 6 months', but this encompass the time span of the 'last 3-6 months' in the original 'MUST' tool. The British Society of Parenteral

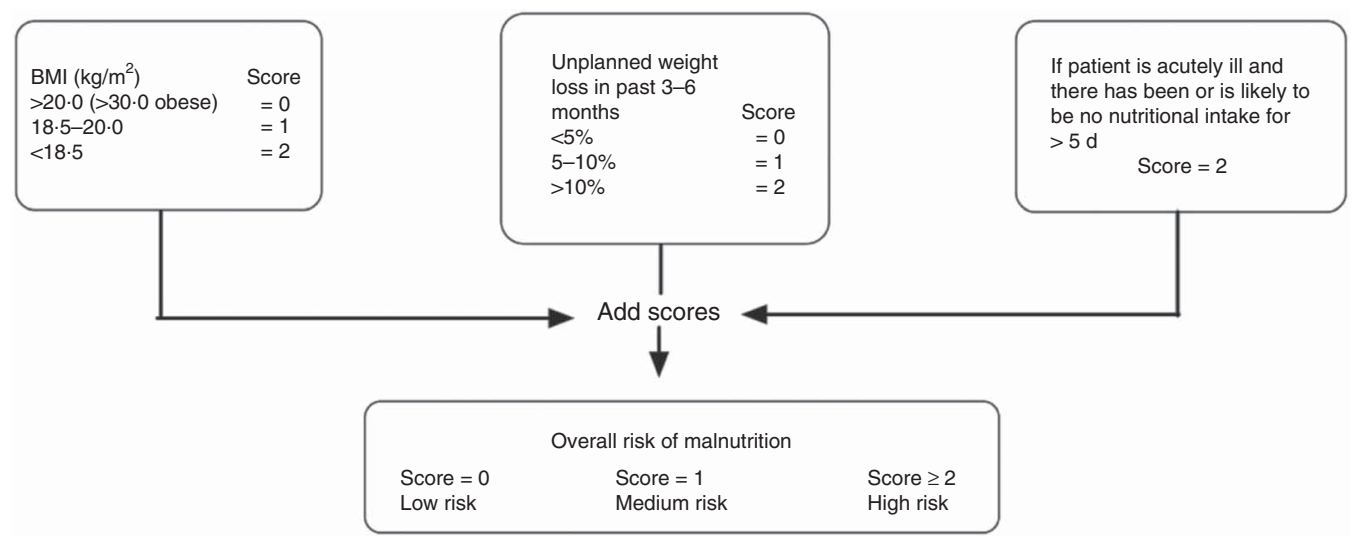

Fig. 1 The Malnutrition Universal Screening Tool (MUST) is composed of a BMI score, a weight-loss score and an acute illness component. The risk of malnutrition can be assessed based on the sum of these scores. The 'MUST' tool is reproduced here with the kind permission of BAPEN (British Association for Parenteral and Enteral Nutrition). For further information on 'MUST' and management guidelines, see www.bapen.org.uk 
and Enteral nutrition (www.bapen.org.uk) developed the 'MUST' tool ${ }^{(14)}$ and it is one of the nutritional screening instruments recommended by the European Society for Parenteral and Enteral nutrition for use in noninstitutionalised elderly ${ }^{(15)}$.

\section{Mental bealth, sociodemographic characteristics and lifestyle factors}

We also aimed to study the association between $\mathrm{Zn}$ deficiency and mental health. The Hopkins Symptoms Check List-10 (SCL-10) was utilised to assess mental health distress. The SCL-10 is a self-administered instrument that primarily explores symptoms of anxiety and depression $^{(16)}$. The ten items of the SCL-10 were part of the self-administered questionnaire that was included in the invitation to participate in the survey. The questionnaire was collected at the research centre. A higher SCL-10 score indicates a greater number of symptoms (score ranging between 1.0 and 4.0 ).

An important source of $\mathrm{Zn}$ in the Western diet is meat ${ }^{(17)}$. Frequency of meat intake during the preceeding week, smoking habits and sociodemographic variables were also obtained from the self-administered questionnaires.

\section{Statistical analysis}

Differences between both men and women and participants according to $\mathrm{Zn}$ status were analysed using the $t$ test, $\chi^{2}$ test or Mann-Whitney $U$ test. The associations between risk of malnutrition (medium and high risk combined) and Zn deficiency were analysed using logistic regression, yielding odds ratio estimates with $95 \%$ confidence intervals. The odds ratio estimates were adjusted for age, smoking status and serum albumin. The SCL-10 score was positively skewed, and the median SCL-10 values with $25-75 \%$ interquartile range are reported. Two-sided $P$ values $<0.05$ were considered statistically significant. The analyses were performed using the statistical software package IMB SPSS Statistics version 19.0.

Each participant provided written informed consent. The study was conducted according to the guidelines of the Declaration of Helsinki.

\section{Results}

A total of 743 men and 778 women were included in the analysis. A risk of malnutrition (medium and high risk combined) was found in $8.0 \%$ of the participants, more often in women $(10 \cdot 4 \%)$ than in men $(5 \cdot 5 \%)$. BMI did not differ between men and women; however, former smoking was more common in men than in women (Table 1).

The mean serum $\mathrm{Zn}$ value was $11.9 \mu \mathrm{mol} / \mathrm{l}$ in both men and women (range $4 \cdot 8-20 \mu \mathrm{mol} / \mathrm{l}$; Table 1 ). The prevalence of $\mathrm{Zn}$ deficiency was $10 \cdot 1 \%$ among all participants, with rates of $13.1 \%$ in men and $7.3 \%$ in women. Among participants at risk of malnutrition, $\mathrm{Zn}$ deficiency was found in $31.7 \%$ of the men and $12.3 \%$ of the women (Fig. 2). With increasing age, Zn deficiency was more prevalent in both men and women (Table 2).

Table 1 Characteristics of participating elderly men and women, the Tromsø Study, 2007-2008*

\begin{tabular}{|c|c|c|c|c|c|c|c|}
\hline & \multicolumn{2}{|c|}{ All $(n$ 1521) } & \multicolumn{2}{|c|}{ Men $(n 743)$} & \multicolumn{2}{|c|}{ Women (n 778) } & \multirow[b]{2}{*}{$P$ value } \\
\hline & $\begin{array}{l}\text { Mean, } \% \text {, } \\
\text { median or range }\end{array}$ & $\begin{array}{l}\text { SD, } n \text { or } \\
\text { IQR }\end{array}$ & $\begin{array}{l}\text { Mean, } \% \text {, } \\
\text { median or range }\end{array}$ & $\begin{array}{l}\text { SD, } n \text { or } \\
\text { IQR }\end{array}$ & $\begin{array}{l}\text { Mean, } \% \text {, } \\
\text { median or range }\end{array}$ & $\begin{array}{l}\text { SD, } n \text { or } \\
\text { IQR }\end{array}$ & \\
\hline Age (years), mean and SD & 71.9 & $5 \cdot 6$ & $71 \cdot 3$ & $5 \cdot 3$ & $72 \cdot 4$ & $5 \cdot 8$ & $<0.01 \ddagger$ \\
\hline \multicolumn{8}{|l|}{ Smoking status, $\%$ and $n$} \\
\hline Never smoked & 35.5 & 528 & $22 \cdot 8$ & 167 & $47 \cdot 8$ & 361 & \\
\hline Previous smoker & $49 \cdot 4$ & 736 & $62 \cdot 2$ & 456 & $37 \cdot 0$ & 280 & $<0.01 \S$ \\
\hline Current smoker & $15 \cdot 1$ & 225 & $15 \cdot 0$ & 110 & $15 \cdot 2$ & 115 & \\
\hline \multicolumn{8}{|l|}{ Nutritional status } \\
\hline BMI $\left(\mathrm{kg} / \mathrm{m}^{2}\right)$, mean and SD & $26 \cdot 9$ & $4 \cdot 1$ & $27 \cdot 0$ & 3.5 & $26 \cdot 9$ & $4 \cdot 6$ & $0.89 \ddagger$ \\
\hline $\begin{array}{l}\text { Medium/high risk of } \\
\text { malnutrition, } \% \text { and } n\end{array}$ & $8 \cdot 0$ & 122 & $5 \cdot 5$ & 41 & $10 \cdot 4$ & 81 & $<0.01 \S$ \\
\hline \multicolumn{8}{|l|}{ Laboratory values } \\
\hline $\begin{array}{l}\text { Serum } \mathrm{Zn}(\mu \mathrm{mol} / \mathrm{l}), \text { mean and SD } \\
\text { Serum } \mathrm{Zn}(\mu \mathrm{mol} / \mathrm{l}) \text {, range }\end{array}$ & $\begin{array}{c}11 \cdot 9 \\
4 \cdot 8-20 \cdot 0\end{array}$ & $1 \cdot 8$ & $\begin{array}{c}11 \cdot 9 \\
4 \cdot 8-18 \cdot 3\end{array}$ & $1 \cdot 8$ & $\begin{array}{c}11 \cdot 9 \\
7 \cdot 6-20 \cdot 0\end{array}$ & 1.7 & $0.94 \ddagger$ \\
\hline Serum $\mathrm{Zn}$ deficiency, $\%$ and $n$ & $10 \cdot 1$ & 154 & $13 \cdot 1$ & 97 & $7 \cdot 3$ & 57 & $<0.01 \S$ \\
\hline Albumin $(\mathrm{g} / \mathrm{l})$, mean and SD & $45 \cdot 1$ & $2 \cdot 3$ & $45 \cdot 3$ & $2 \cdot 2$ & $44 \cdot 8$ & $2 \cdot 3$ & $<0.01 \ddagger$ \\
\hline \multicolumn{8}{|l|}{ Mental health score } \\
\hline SCL-10 score, median and IQR & $1 \cdot 1$ & $1 \cdot 0-1 \cdot 3$ & $1 \cdot 1$ & $1 \cdot 0-1 \cdot 3$ & $1 \cdot 2$ & $1 \cdot 1-1 \cdot 5$ & $<0.01 \|$ \\
\hline
\end{tabular}

IQR, interquartile range; SCL-10, Hopkins Symptoms Check List-10.

*There are minor differences in the number of evaluated individuals due to variations in missing values on the self-administered questionnaire regarding smoking.

† $P$ value for differences between men and women.

$\ddagger P$ value from the $t$ test.

$\S P$ value from the $x^{2}$ test.

$\| P$ value from the Mann-Whitney $U$ test. 


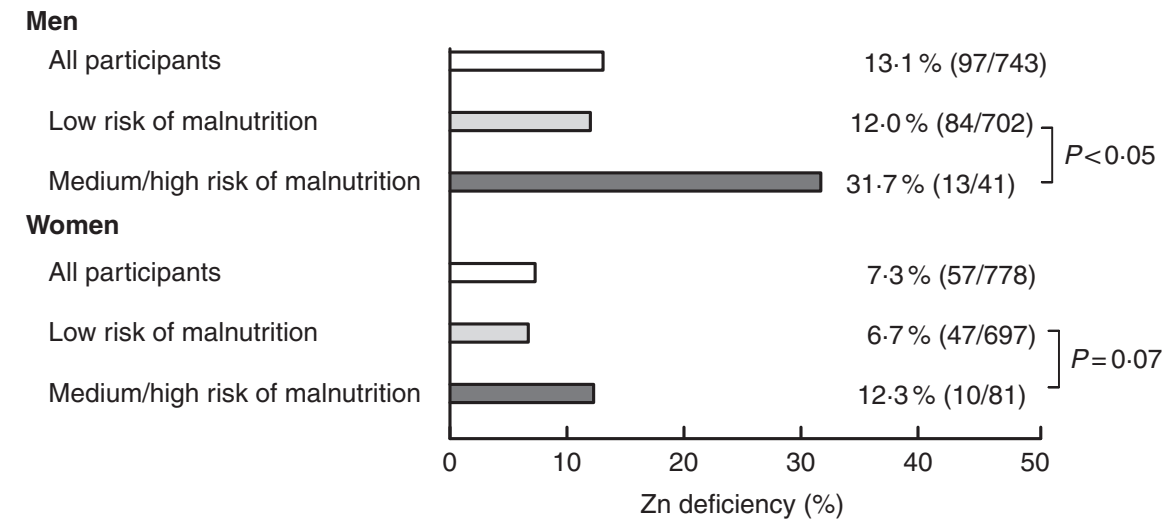

Fig. 2 Zinc deficiency, given as \% and ( $n / N$, the number of subjects with zinc deficiency/number of subjects in the group) for all men and women, as well as for low and medium/high risk categories of malnutrition, the Tromsø Study, 2007-2008

Table 2 Prevalence of zinc deficiency in different age categories of elderly men and women, the Tromsø Study, 2007-2008

\begin{tabular}{|c|c|c|c|c|c|c|}
\hline \multirow[b]{2}{*}{ Age range (years) } & \multicolumn{2}{|c|}{ All } & \multicolumn{2}{|c|}{ Men } & \multicolumn{2}{|c|}{ Women } \\
\hline & Prevalence (\%) & $n / N^{*}$ & Prevalence (\%) & $n / N^{*}$ & Prevalence (\%) & $n / N^{*}$ \\
\hline $64-71$ & 8.9 & $75 / 843$ & $12.0 \dagger$ & $53 / 441$ & 5.5 & $22 / 402$ \\
\hline $72-78$ & $9 \cdot 4$ & $43 / 456$ & 12.0 & $26 / 217$ & $7 \cdot 1$ & $17 / 239$ \\
\hline $79-87$ & $16 \cdot 2$ & $36 / 222$ & 21.2 & $18 / 85$ & $13 \cdot 1$ & $18 / 137$ \\
\hline$P$ value $\dagger$ & \multicolumn{2}{|c|}{0.005} & \multicolumn{2}{|c|}{0.07} & \multicolumn{2}{|c|}{0.005} \\
\hline
\end{tabular}

*Number of subjects with $\mathrm{Zn}$ deficiency/number of subjects in the age group.

$\dagger P$ value for linear by linear association between age categories.

Table 3 Characteristics of the participating elderly men and women* according to zinc status, the Tromsø Study, 2007-2008

\begin{tabular}{|c|c|c|c|c|c|c|c|c|c|c|}
\hline & \multicolumn{4}{|c|}{ Men $(n$ 743) } & \multicolumn{5}{|c|}{ Women ( $n$ 778) } & \multirow[b]{4}{*}{$P$ value- } \\
\hline & \multicolumn{4}{|c|}{ Zn status } & & \multicolumn{4}{|c|}{ Zn status } & \\
\hline & \multicolumn{2}{|c|}{ Zn-deficient ( $n$ 97) } & \multicolumn{2}{|c|}{ Zn-normal (n 646) } & \multirow[b]{2}{*}{$P$ value† } & \multicolumn{2}{|c|}{ Zinc-deficient $(n 57)$} & \multicolumn{2}{|c|}{ Zn-normal (n 721) } & \\
\hline & $\begin{array}{l}\text { Mean, \% or } \\
\text { median }\end{array}$ & $\begin{array}{l}\text { SD, } n \text { or } \\
\text { IQR }\end{array}$ & $\begin{array}{l}\text { Mean, } \% \text { or } \\
\text { median }\end{array}$ & $\begin{array}{l}\text { SD, } n \text { or } \\
\text { IQR }\end{array}$ & & $\begin{array}{l}\text { Mean, } \% \text { or } \\
\text { median }\end{array}$ & $\begin{array}{l}\text { SD, } n \text { or } \\
\text { IQR }\end{array}$ & $\begin{array}{l}\text { Mean, \% or } \\
\text { median }\end{array}$ & $\begin{array}{l}\text { sD, } n \text { or } \\
\text { IQR }\end{array}$ & \\
\hline Age (years), mean and SD & $72 \cdot 2$ & 5.9 & $71 \cdot 2$ & $5 \cdot 2$ & $0.02 \ddagger$ & $74 \cdot 7$ & 6.5 & $72 \cdot 2$ & $5 \cdot 7$ & $0.07 \ddagger$ \\
\hline $\begin{array}{l}\text { Single marital status, \% and } n \\
\text { Smoking status, \% and } n\end{array}$ & $26 \cdot 8$ & 26 & $22 \cdot 4$ & 145 & $0.41 \S$ & $63 \cdot 2$ & 36 & $49 \cdot 8$ & 359 & $0.07 \S$ \\
\hline Never & $27 \cdot 7$ & 26 & $22 \cdot 1$ & 141 & & $56 \cdot 4$ & 31 & $47 \cdot 1$ & 330 & \\
\hline Previous & 58.5 & 55 & $62 \cdot 8$ & 401 & $0.48 \S$ & $30 \cdot 9$ & 17 & 37.5 & 263 & $0.41 \S$ \\
\hline Current & $13 \cdot 8$ & 13 & $15 \cdot 2$ & 97 & & $12 \cdot 7$ & 7 & $15 \cdot 4$ & 108 & \\
\hline \multicolumn{11}{|l|}{ Nutritional status, $\%$ and $n$} \\
\hline $\begin{array}{l}\text { Medium/high risk of } \\
\text { malnutrition }\end{array}$ & $13 \cdot 4$ & 13 & $4 \cdot 3$ & 28 & $0.01 \S$ & $17 \cdot 5$ & 10 & $9 \cdot 8$ & 17 & $0.07 \S$ \\
\hline \multicolumn{11}{|l|}{ Nutritional intake, $\%$ and $n$} \\
\hline $\begin{array}{l}\text { Meat intake } \leq 3 \text { times/week } \\
\text { Mental health }\end{array}$ & $20 \cdot 2$ & 18 & $18 \cdot 8$ & 114 & $0.85 \S$ & $34 \cdot 7$ & 17 & $28 \cdot 1$ & 181 & $0.41 \S$ \\
\hline $\begin{array}{l}\text { SCL-10 score, median and } \\
\text { IQR }\end{array}$ & $1 \cdot 1$ & $1 \cdot 0-1 \cdot 3$ & $1 \cdot 1$ & $1 \cdot 0-1 \cdot 2$ & $0.93 \|$ & $1 \cdot 2$ & $1 \cdot 1-1.5$ & $1 \cdot 2$ & $1 \cdot 1-1 \cdot 4$ & $0 \cdot 77 \|$ \\
\hline \multicolumn{11}{|c|}{ Supplementary laboratory values } \\
\hline Albumin $(\mathrm{g} / \mathrm{l})$, mean and SD & $44 \cdot 3$ & $2 \cdot 4$ & $45 \cdot 5$ & $2 \cdot 2$ & $<0.05 \ddagger$ & $43 \cdot 6$ & $2 \cdot 7$ & $44 \cdot 9$ & $2 \cdot 2$ & $<0.05 \ddagger$ \\
\hline
\end{tabular}

IQR, interquartile range; SCL-10, Hopkins Symptoms Check List-10.

*There are minor differences in the number of evaluated individuals due to variations in missing values on the self-administered questionnaire regarding smoking. $\dagger P$ value for differences between groups.

$\ddagger P$ value from the $t$ test.

$\S P$ value from the $X^{2}$ test.

$\| P$ value from the Mann-Whitney $U$ test.

The mean albumin level was $45 \cdot 1 \mathrm{~g} / \mathrm{l}$ (range $35.7-51.9 \mathrm{~g} / \mathrm{l}$ ) and the albumin level was slightly lower in Zn-deficient individuals (Table 3).
The association between Zn deficiency and risk of malnutrition was further analysed using logistic regression. Zn deficiency was positively associated with the risk of 
malnutrition both in a model adjusted for gender only $(\mathrm{OR}=2 \cdot 6 ; 95 \%$ CI $1 \cdot 6,4 \cdot 2)$ and in a model adjusted for gender, age, smoking status and serum albumin $(\mathrm{OR}=2 \cdot 2$; $95 \%$ CI $1 \cdot 3,3 \cdot 6$ ).

The reported weekly frequency of meat intake was not lower in the participants with Zn deficiency (Table 3). Mental health distress, as assessed by the SCL-10 score, was reported more frequently by women than by men (Table 1). However, no significant differences in mental health distress were found between the two categories of Zn status in men or women (Table 3).

\section{Discussion}

In this population-based study of elderly men and women, we found that, based on a low serum $\mathrm{Zn}$ concentration, one out of ten individuals had Zn deficiency. However, in elderly men at risk of malnutrition, one out of three had $\mathrm{Zn}$ deficiency. In women, the corresponding proportion was lower, but the value was still significantly increased compared with that in women not at risk of malnutrition.

\section{Prevalence of zinc deficiency in elderly individuals} Previous studies of $\mathrm{Zn}$ status in elderly individuals largely explored smaller populations and various cut-offs for $\mathrm{Zn}$ deficiency have been applied. A Norwegian study of home-living elderly individuals revealed that four out of ninety-seven participants had serum $\mathrm{Zn}$ levels below $8 \mu \mathrm{mol} / \mathrm{l}^{(18)}$. In a European multicentre study that included 853 elderly individuals from Italy, Greece, Germany, France and Poland, a slightly higher cut-off $(11.0 \mu \mathrm{mol} / \mathrm{l})$ was used, resulting in the classification of $31 \%$ of the participants as $\mathrm{Zn}$-deficient ${ }^{(5)}$. Applying the same cut-off value to the present study sample would have revealed a similar Zn deficiency prevalence rate (28\%).

In the present study, the prevalence of $\mathrm{Zn}$ deficiency increased significantly with increasing age (Table 2 ). Some previous studies of $\mathrm{Zn}$ deficiency compared the old and oldest old, but most studies included a small number of participants. In the ZENITH study of 387 participants from France, the UK and Italy, the prevalence of $\mathrm{Zn}$ deficiency was similar between old and oldest old individuals ${ }^{(19)}$. However, in another study from Italy, the oldest old had significantly lower levels of plasma $\mathrm{Zn}$ compared with the $\mathrm{old}^{(20)}$. This age-associated increase in $\mathrm{Zn}$ deficiency may be explained by several factors, including both an agerelated decline in the absorptive capacity of the small bowel and a general decline in energy and food intake in the oldest old ${ }^{(10)}$.

\section{Risk of malnutrition and zinc deficiency}

The relationship between the risk of malnutrition and serum $\mathrm{Zn}$ was previously explored in a study of fifty hospitalised patients using the Mini Nutritional Assessment tool $^{(8)}$. In that study, no association was found between $\mathrm{Zn}$ status and the risk of malnutrition. A population-based study of elderly individuals using the 'MUST' tool showed lower mean $\mathrm{Zn}$ values in individuals at risk of malnutrition $^{(9)}$. However, the proportion of malnourished elderly individuals with $\mathrm{Zn}$ deficiency was not estimated.

Several mechanisms may explain the observed associations between malnutrition and Zn deficiency. First, Zn deficiency may produce altered taste and smell, resulting in reduced appetite and consequent weight loss and malnutrition ${ }^{(21)}$. Second, a reduced intake of $\mathrm{Zn}$ containing food in malnourished elderly individuals may result in reduced body $\mathrm{Zn}$. In Western diets, meat (beef and pork) is the most important source of $\mathrm{Zn}$, contributing approximately $50 \%$ of the total $\mathrm{Zn}$ intake ${ }^{(17)}$.

The recommendations for the intake of $\mathrm{Zn}$ are similar for elderly and other adult individuals. In the present study, no association was found between the reported intake of meat per day and Zn deficiency. However, more detailed information regarding the intake of $\mathrm{Zn}$-containing foods was not available; in general, it may be difficult to obtain valid data concerning food habits from selfadministered questionnaires ${ }^{(22)}$.

One strength of the present study is the strictly population-based design and the relatively large study population. The Troms $\varnothing$ Study includes populations from both urban and rural areas and may be regarded as relatively homogeneous with respect to both ethnicity and living conditions. The external validity (to other countries) of our results regarding the association between risk of malnutrition and $\mathrm{Zn}$ deficiency in community-living elderly individuals may, of course, be questioned, but it is likely that the positive relationship between the two variables that we demonstrate is generalisable. There is, however, a need for more studies in diverse populations which may confirm or refute our conclusions.

A potential problem is the assessment of $\mathrm{Zn}$ status by serum $\mathrm{Zn}$ as only a small proportion of the body $\mathrm{Zn}$ is present in the serum pool. The assessment of $\mathrm{Zn}$ status is challenging and several biomarkers and methods have been suggested, such as the measurement of $\mathrm{Zn}$ in hair, erythrocytes and serum or plasma. However, serum (or plasma) $\mathrm{Zn}$ is the recommended method for the assessment of $\mathrm{Zn}$ status in larger populations ${ }^{(23,24)}$. The optimal indicator of individual $\mathrm{Zn}$ status has not been identified and caution should be used when applying serum (or plasma) $\mathrm{Zn}$ in an individual setting.

Furthermore, we did not collect information about sources of $\mathrm{Zn}$ such as micronutrient supplementation containing $\mathrm{Zn}$ and the consumption of $\mathrm{Zn}$-fortified foods. Participation in the study required the ability to fill out a self-administered questionnaire and to visit a research centre. These requirements may have led to a bias in the sampling because elderly people with cognitive decline or mental illness may have been less willing to participate in the study. The blood collection tubes were free of trace 
elements, but the needles were of standard type. Thus, the needles may have introduced contamination with $\mathrm{Zn}$ and increased the plasma $\mathrm{Zn}$ concentration.

The level of serum $\mathrm{Zn}$ may be related to that of serum albumin. The majority of $\mathrm{Zn}$ in the serum is bound to albumin and it has been proposed that a reduction of $\mathrm{Zn}$ binding sites in hypoalbuminaemia may influence the serum Zn level. However, a reduced Zn status may also inhibit albumin synthesis ${ }^{(25)}$. Although albumin is not a reliable marker of nutritional status, a reduction in serum albumin can be observed in some patients with malnutrition. This reduction may be explained by coexisting comorbidity and inflammation ${ }^{(26)}$. We therefore compared serum albumin levels between the low and normal $\mathrm{Zn}$ groups. The albumin levels were lower in both men and women with $\mathrm{Zn}$ deficiency. However, no individuals exhibited an albumin level below $35 \mathrm{~g} / \mathrm{l}$, which is regarded as the cut-off value defining a significant effect of albumin level on serum $\mathrm{Zn}$ concentration ${ }^{(13)}$. Moreover, the inclusion of albumin in the model of the relationship between Zn deficiency and malnutrition only slightly changed the odds ratio estimate.

No significantly high levels of $\mathrm{Zn}$ were detected in this study sample. High levels of serum $\mathrm{Zn}$ occur only during supplementation with $\mathrm{Zn}^{(13)}$ and in Norway, supplements containing significant amounts of $\mathrm{Zn}$ are primarily obtained by prescription. No data on supplement consumption was available in the present study.

$\mathrm{Zn}$ is not often analysed in clinical practice, as other micronutrients are more closely associated with specific functions. As an example, Fe and folate are required for $\mathrm{Hb}$ production, the deficiency of which can be manifested by anaemia and is thus more easily detected. In contrast, $\mathrm{Zn}$ is necessary for general metabolism and manifestations of any deficiency may therefore be more elusive than those associated with other micronutrients ${ }^{(25)}$.

\section{Impact of zinc deficiency}

The impact of mild to moderate $\mathrm{Zn}$ deficiency has not been fully explored. Previous research has provided evidence for the impairment of the T-lymphocyte balance due to such deficiency, resulting in an impaired immune system and moderate $\mathrm{Zn}$ deficiencies in elderly men and women ${ }^{(27)}$. Studies of nursing home residents suggested an increased level of pneumonia in Zn-deficient individuals and a reduction in the risk of pneumonia following Zn supplementation ${ }^{(28)}$.

Furthermore, some studies have linked Zn deficiency to depression and other psychiatric disorders, mostly based on studies of psychiatric in- and out-patients ${ }^{(29,30)}$. We used the SCL-10 instrument for the assessment of psychiatric symptoms. This instrument has been widely used in epidemiological studies including elderly people. The SCL-10 captures symptoms of both anxiety and depression, which often appear together as comorbid disorders ${ }^{(16)}$. However, in the present study, we found no association between $\mathrm{Zn}$ deficiency and symptoms of anxiety or depression in community-living elderly individuals.

\section{Conclusion}

In this population-based study, we found $\mathrm{Zn}$ deficiency to be associated with the risk of malnutrition. Overall, $\mathrm{Zn}$ deficiency was found in one out of ten community-living elderly people. Although caution should be taken when applying serum (or plasma) $\mathrm{Zn}$ as an indicator of individual $\mathrm{Zn}$ status, our results support a special attention on Zn deficiency in elderly people at risk of malnutrition, particularly elderly men.

\section{Acknowledgements}

Financial support: This study was supported by a research grant from the Northern Regional Health Authority (grant number 778-08). The funder had no role in the design, analysis or writing of this article. The Tromsø 6 study was carried out by The University of Troms $\varnothing$, Department of Community Medicine. Conflict of interest: None. Authorship: J.-M.K., O.G. and J.F. were responsible for the initial design of the study. J.-M.K. performed the analysis and wrote the first draft of the paper. All authors contributed to the critical revision of the article and approved the final version to be published. Ethics of human subject participation: Each participant provided written informed consent prior to inclusion in the study. The Troms $\varnothing 6$ study was approved by the Regional Board of Research Ethics in Northern Norway (http://helseforskning.etikkom.no/xnet/ public/side?p_dim=11928; approval number 200605174-12/ IAY/400). The study was performed in accordance with the ethical standards of the 1964 Declaration of Helsinki.

\section{References}

1. Kaplan LA, Pesce AJ \& Kazmierczak SC (2003) Clinical Chemistry. Theory, Analysis, Correlation, 4th ed. St Louis, MO: Mosby.

2. Tuerk MJ \& Fazel N (2009) Zinc deficiency. Curr Opin Gastroenterol 25, 136-143.

3. Barnett JB, Hamer DH \& Meydani SN (2010) Low zinc status: a new risk factor for pneumonia in the elderly? Nutr Rev 68, 30-37.

4. McClain CJ, McClain M, Barve S et al. (2002) Trace metals and the elderly. Clin Geriatr Med 18, 801-818.

5. Marcellini F, Giuli C, Papa R et al. (2006) Zinc status, psychological and nutritional assessment in old people recruited in five European countries: Zincage study. Biogerontology 7, 339-345.

6. Walker CF, Ezzati M \& Black R (2008) Global and regional child mortality and burden of disease attributable to zinc deficiency. Eur J Clin Nutr 63, 591-597.

7. High KP (1999) Micronutrient supplementation and immune function in the elderly. Clin Infect Dis 28, 717-722.

8. Pepersack T, Rotsaert P, Benoit F et al. (2011) Prevalence of zinc deficiency and its clinical relevance among hospitalised elderly. Arch Gerontol Geriatr 33, 243-253. 
9. Margetts BM, Thompson RL, Elia M et al. (2003) Prevalence of risk of undernutrition is associated with poor health status in older people in the UK. Eur J Clin Nutr 57, 69-74.

10. Haase H \& Rink L (2009) The immune system and the impact of zinc during aging. Immun Ageing 6, 9.

11. Jacobsen BK, Eggen AE, Mathiesen EB et al. (2012) Cohort profile: the Troms $\varnothing$ study. Int J Epidemiol 41, 961-967.

12. Eggen AE, Mathiesen EB, Wilsgaard T et al. (2013) The sixth survey of the Tromso Study (Tromso 6) in 2007-08: collaborative research in the interface between clinical medicine and epidemiology: study objectives, design, data collection procedures, and attendance in a multipurpose populationbased health survey. Scand J Public Health 41, 65-80.

13. International Zinc Nutrition Consultative Group (IZiNCG), Brown KH, Rivera JA et al. (2004) International Zinc Nutrition Consultative Group (IZiNCG) technical document \#1. Assessment of the risk of zinc deficiency in populations and options for its control. Food Nutr Bull 25, 1 Suppl. 2, S99-S203.

14. Elia M (2003) The 'MUST' Report. Nutritional Screening of Adults: A Multidisciplinary Responsibility. Redditch: Malnutrition Advisory Group/British Association for Parenteral and Enteral Nutrition.

15. Kondrup J, Allison SP, Elia M et al. (2003) ESPEN guidelines for nutrition screening 2002. Clin Nutr 22, 415-421.

16. Strand BH, Dalgard OS, Tambs K et al. (2003) Measuring the mental health status of the Norwegian population: a comparison of the instruments SCL-25, SCL-10, SCL- 5 and MHI-5 (SF-36). Nord J Psychiatry 57, 113-118.

17. Maret W \& Sandstead HH (2006) Zinc requirements and the risks and benefits of zinc supplementation. I Trace Elem Med Biol 20, 3-18.

18. Lundgren B, Mowe M, Norseth J et al. (2002) Zinc deficiency is of limited clinical importance in the elderly $(>69 y)$ of Oslo. J Nutr Health Aging 6, 243-244.

19. Andriollo-Sanchez M, Hininger-Favier I, Meunier N et al. (2005) Zinc intake and status in middle-aged and older
European subjects: the ZENITH study. Eur J Clin Nutr 59, Suppl. 2, S37-S41.

20. Ravaglia G, Forti P, Maioli F et al. (2000) Blood micronutrient and thyroid hormone concentrations in the oldestold. J Clin Endocrinol Metab 85, 2260-2265.

21. Yagi T, Asakawa A, Ueda $\mathrm{H}$ et al. (2013) The role of zinc in the treatment of taste disorders. Recent Pat Food Nutr Agric 5, 44-51.

22. Willett WC (2008) Nutritional epidemiology. In Modern Epidemiology, 3rd ed., pp. 580-597 [KJ Rothman, S Greenland and TL Lash, editors]. Philadelphia, PA: Lippincott Williams \& Wilkins.

23. Lowe NM, Fekete K \& Decsi T (2009) Methods of assessment of zinc status in humans: a systematic review. $A m \mathrm{~J}$ Clin Nutr 89, issue 6, 2040S-2051S.

24. de Benoist B, Darnton-Hill I, Davidsson L et al. (2007) Conclusions of the Joint WHO/UNICEF/IAEA/IZiNCG Interagency Meeting on Zinc Status Indicators. Food Nutr Bull 28, 3 Suppl., S480-S484.

25. King JC (2011) Zinc: an essential but elusive nutrient. Am J Clin Nutr 94, issue 2, 679S-684S.

26. Omran ML \& Morley JE (2000) Assessment of protein energy malnutrition in older persons, Part II: Laboratory evaluation. Nutrition 16, 131-140.

27. Uciechowski P, Kahmann L, Plümäkers B et al. (2008) TH1 and TH2 cell polarization increases with aging and is modulated by zinc supplementation. Exp Gerontol $\mathbf{4 3}$, 493-498.

28. Barnett JB, Hamer DH \& Meydani SN (2010) Low zinc status: a new risk factor for pneumonia in the elderly? Nutr $\operatorname{Rev}$ 68, 30-37.

29. Swardfager W, Herrmann N, Mazereeuw G et al. (2013) Zinc in depression: a meta-analysis. Biol Psychiatry $\mathbf{7 4}$, 872-878.

30. Grønli O, Kvamme JM, Friborg O et al. (2013) Zinc deficiency is common in several psychiatric disorders. PLoS One 8, E82793. 